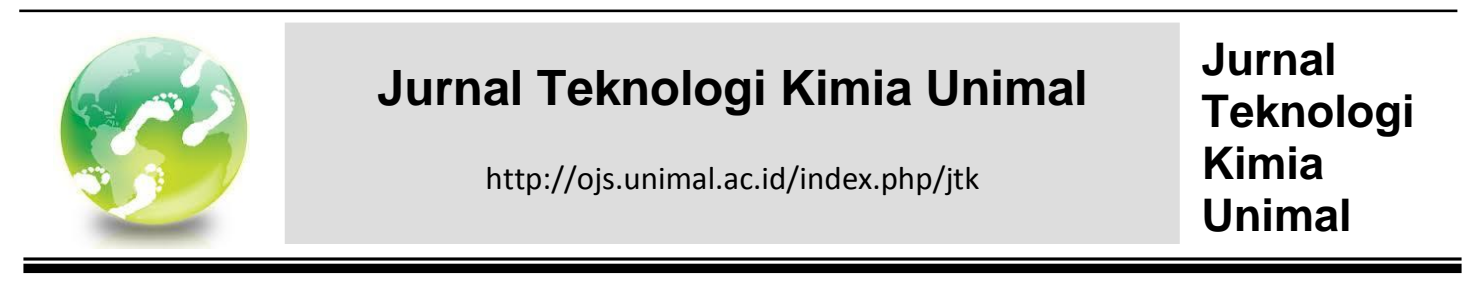

\title{
SINTESIS BIOPLASTIK DARI PATI BIJI ALPUKAT DENGAN BAHAN PENGISI KITOSAN
}

\author{
Muhammad*, Rina Ridara, Masrullita \\ Jurusan Teknik Kimia, Fakultas Teknik, Universitas Malikussaleh \\ 24352, Aceh Utara, Indonesia. \\ E-mail: $\underline{\text { mhdtk@unimal.ac.id }}$
}

\begin{abstract}
Abstrak
Penelitian bioplastik dari pati biji alpukat telah berhasil dilaksanakan, hal ini dilakukan tidak lain adalah untuk berkontribusi dalam usaha meminimasi masalah tumpukan limbah plastik sintetik. Biji alpukat dapat dijadikan sebagai prekursor bioplastik karena kandungan patinya yang cukup tinggi. Bioplastik berbahan dasar pati alpukat memberikan karakteristik mekanik yang rendah sehingga perlu ditambah kitosan dan gliserol sebagai penguat. Penelitian ini dilakukan untuk mempelajari komposisi optimal terhadap kualitas bioplastik dari pati biji alpukat. Pelarut yang digunakan pada pembuatan bioplastik kitosan yaitu asam asetat $1 \%$ serta plasticizer gliserol sebanyak $7 \mathrm{ml}$ dan $10 \mathrm{ml}$. Penelitian ini terdiri dari ekstraksi pati biji alpukat beserta karakterisasinya, pembuatan bioplastik, uji mekanik, uji daya serap air, dan uji biodegradasi. Nilai kuat tarik bioplastik paling tinggi adalah 4,00 Mpa, didapat pada sampel BPS 10 dengan komposisi kitosan 2,5 gr dan volume gliserol $10 \mathrm{ml}$. Untuk nilai persen pemanjangan (elongasi) terbaik didapat pada sampel BPS 6 yaitu sebesar 54,5\% juga dengan komposisi kitosan 0,5 gr dan volume gliserol $10 \mathrm{ml}$. Kuat tarik berbanding terbalik dengan persen pemanjangan. Hasil yang didapat dari indeks swelling yang terbaik terdapat pada sampel BPS 6 yaitu sebesar 10,32\% dengan komposisi kitosan 0,5 gr dan volume gliserol $10 \mathrm{ml}$. Proses penguraian bioplastik sampai dengan $100 \%$ membutuhkan waktu degradasi selama 16 hari.
\end{abstract}

\section{Kata kunci: $\quad$ Bioplastik, biji alpukat, biodegradabel, Kitosan.}

\section{Pendahuluan}

Plastik berbasis minyak bumi sangat mencemari lingkungan, karena tidak bisa terurai secara alami. Akibat permasalahan lingkungan yang ditimbulkan oleh tumpukan limbah plastik nonbiodegradabel telah tergugah para penelitian untuk mengembangkan bahan plastik biodegradabel dengan karakteristiknya yang memungkinkan untuk dikembangkan dalam skala komersial.

Pati merupakan salah satu prekursor biopolimer yang menarik karena mudah didapat, harganya murah, dan memiliki potensi aplikasi untuk melahirkan plastik biodegradable. Plastik biodegradabel menjadi alternatif bahan kemasan yang ramah lingkungan, karena plastik biodegradabel merupakan polimer yang terbuat dari bahan secara alami dan mudah terdegradasi oleh mikroorganisme. Namun, plastik berbasis pati juga punya sisi kelemahan, yaitu sifat yang hidrofiliknya 
(Shirai, dkk., 2013) dan sifat mekanik yang rendah, tatapi kelemahan ini masih dapat diatasi dengan menambahkan kitosan sebagai bahan pengisinya (filler).

Komposisi dari biji alpukat yang mengandung pati sebesar $80,1 \%$ dengan kadar amilosa 43,3\% dan amilopektin 36,8\% (Winarti dan Purnomo, 2006) adalah menjadi dasar inisiasi penggunaannya sebagai bahan baku pembuatan bioplastik.

Kitosan merupakan turunan kitin yang bersifat hidrofobik (Dallan et al., 2006). Kitosan merupakan biomaterial yang didapatkan dengan cara deasitilasi kitin dari kulit udang dengan natrium hidroksida. Karena sifat kitosan yang ramah lingkungan dan tidak beracun maka kitosan banyak digunakan untuk mensintesis material yang bersifat biodegradable (Khantayanuwong, 2016). Penggunaan kitosan sebagai bahan pengisi pada proses sintesis bioplastik karena kitosan dapat membentuk lapis tipis yang bening, kuat, dan fleksibel (Mackay dan Tait, 2011).

Bioplastik berbahan dasar pati-kitosan juga masih memiliki kelemahan yaitu rendahnya nilai elastisitas. Nilai elastisitas yang rendah ini dapat ditingkatkan atau diperbaiki dengan cara menambahkan plasticizer. Untuk mengubah sifat mekanik bioplastik maka Krochta (2002) menggunakan bahan pengisi berupa plasticizer. Penambahan plasticizer dapat meningkatkan mobilitas serta fleksibelitas plastik sehingga dapat mengatasi sifat rapuh dari bioplastik (Darni, 2010). Upaya untuk meningkatkan elastisitas dan menurunkan tingkat kekakuan dari bioplastik yang akan dihasilakn maka pada penelitian ini peneliti menggunakan pemlastis jenis gliserol.

Tujuan dari penelitian ini adalah untuk mengkaji karakteristik dari beberapa pengujian seperti kuat tarik, perpanjangan putus, kecepatan daya urai dan mempelajari komposisi optimal terhadap kualitas dari pati biji alpukat serta menganalisa karakteristik bioplastik yang ramah lingkungan dari pati biji alpukat.

\section{Bahan dan Metode}

\subsection{Bahan}

Material yang digunakan pada penelitian ini adalah pati biji alpukat yang telah dikeringkan dengan sinar matahari kemudian dikeringkan kembali dengan menggunakan oven pada temperature $105^{\circ} \mathrm{C}$ selama 20 menit untuk menghilangkan kadar air yang ada di dalam pati. Bahan-bahan lain yang digunakan meliputi gliserol, asam asetat $1 \%$, pati biji alpukat, kitosan, dan aquades.

\subsection{Metode}

Upaya untuk mendapatkan pati biji alpukat dilakukan dengan cara ekstraksi, yaitu dengan cara merendam irisan biji alpukat (kecil dan tipis) dalam air bersih selama 24 jam. Irisan biji alpukat tersebut kemudian dicuci bersih hingga tidak terdapat lendir yang menempel pada irisan biji alpukat tersebut dan di blender dengan perbandingan 1:1 hingga terbentuk slurry, kemudian slurry tersebut diperas, disaring dan filtrat yang diperoleh didiamkan selama 12 jam hingga terdapat adanya endapan. 
Pembuatan bioplastik dilakukan dengan berat pati sebanyak $10 \mathrm{~g}$ dan variasi kitosan seberat 0,$5 ; 1 ; 1,5 ; 2 ; 2,5 \mathrm{~g}$. Pati dilarutkan dalam aquadest $40 \mathrm{ml}$, sedangkan kitosan dilarutkan dalam asam asetat 1\% dengan pengadukan selama \pm 20 menit. Konsentrasi larutan pati dan larutan kitosan masing-masing $10 \mathrm{~g} / 100$ ml. Setelah kedua larutan tersebut diaduk dan tercampur secara homogen lalu di panaskan pada suhu $70{ }^{\circ} \mathrm{C}$ dengan menggunakan hot plate selama \pm 30 menit tanpa menambahkan gliserol sebagai plasticizer. Selanjutnya ditambahkan variasi gliserol sebesar $7 \mathrm{ml}$ dan $10 \mathrm{ml}$, larutan yang telah tercampur secara sempurna dituang kedalam cetakan (casting) terbuat dari kaca yang berukuran $20 \times 20 \mathrm{~cm}$ dan diangin-anginkan selama \pm 48 jam hingga cukup kering agar mempermudah bioplastik dilepaskan dari cetakan. Sampel bioplastik yang telah dilepas dari cetakan kemudian dilakukan uji daya serap air (swelling), uji degradasi, uji kuat tarik, dan elongasi.

Pengujian daya serap air atau \% swelling dilakukan mengikuti metode yang di lakukan oleh AOAC (1983), uji penyerapan air dilakukan dengan memotong plastik berukuran diameter $50 \mathrm{~mm}$ kemudian sampel ditimbang beratnya. Besarnya daya serap air dapat ditaksirkan dengan persamaan (1):

Penyerapan air $(\%)=\frac{W-W o}{W o} \times 100 \%$

Keterangan :

Wo = berat sampel kering

$\mathrm{W}=$ berat sampel setelah direndam air.

Pengujian degradasi sampel bioplastik dilakukan untuk mengetahui tingkat penguraian plastik. Perhitungan waktu penguraiannya dengan melakukan monotoring secara berkala selama 4 hari sekali. Penguraian sampel bioplastik dapat ditaksirkan dengan persamaan (2):

Biodegradabillity $=\frac{\text { Berat Awal }- \text { Berat Akhir }}{\text { Berat Awal }} \times 100 \%$

\section{Hasil dan Pembahasan}

Pembuatan plastik berbasis pati biji alpukat telah dilakukan dan diperoleh Plastik biodegradabel berupa lembaran plastik yang berwarna coklat. Warna coklat yang didapat pada sampel bioplastik diperoleh dari hasil pengirisan biji alpukat yang berubah dari warna putih menjadi warna merah kecoklatan saat dibiarkan di udara bebas. Hal ini dikarenakan biji alpukat mengandung senyawa fenolik dopa (3,4 dihidroksi fenilalanin). Senyawa fenofilik tersebut dapat menyebabkan adanya reaksi pencoklatan (browning) enzimatik yang disebabkan oleh reaksi antara oksigen dengan substrat fenolik dengan katalisator polifenol oksidase.

\subsection{Uji Swelling}


Uji ketahanan bioplastik dilakukan untuk mengetahui terjadinya ikatan dalam polimer serta struktur ikatan dalam polimer yang ditentukan melalui penambahan berat polimer setelah terjadinya penyerapan air. Sifat ketahanan bioplastik terhadap air ditentukan dengan uji swelling, yaitu penggebungan plastik oleh adanya air.

Parameter baik atau tidaknya kualitas dari bioplastik berbasis pati biji alpukat ini salah satunya dipengaruhi oleh daya serap air. Semakin tinggi kemampuan bioplastik menyerap air maka semakin rendah kualitas dari bioplastik tersebut karena berkaitan dengan ketahanannya saat disimpan. Pada penelitian ini sampel bioplastik di rendam pada suhu ruangan $\left(30^{\circ} \mathrm{C}\right)$.

Tabel 1. Hasil Analisa Swelling Indeks

\begin{tabular}{|c|c|c|c|c|c|}
\hline \multirow{2}{*}{ Sampel } & \multicolumn{5}{|c|}{ Aquadest } \\
\cline { 2 - 6 } & Gliserol & Kitosan & W0 (gr) & W (gr) & $\mathbf{A ~ ( \% ) ~}$ \\
\hline Bioplastik (BPS-1) & 7 & 0,5 & 0,1737 & 0,2007 & 13,45 \\
\hline Bioplastik (BPS-2) & 7 & 1 & 0,2692 & 0,3277 & 17,85 \\
\hline Bioplastik (BPS-3) & 7 & 1,5 & 0,2323 & 0,3185 & 27,06 \\
\hline Bioplastik (BPS-4) & 7 & 2 & 0,3533 & 0,5280 & 33,09 \\
\hline Bioplastik (BPS-5) & 7 & 2,5 & 0,2770 & 0,4443 & 37,65 \\
\hline Bioplastik (BPS-6) & 10 & 0,5 & 0,2547 & 0,2840 & 10,32 \\
\hline Bioplastik (BPS-7) & 10 & 1 & 0,2243 & 0,2702 & 16,99 \\
\hline Bioplastik (BPS-8) & 10 & 1,5 & 0,3527 & 0,4851 & 27,29 \\
\hline Bioplastik (BPS-9) & 10 & 2 & 0,3697 & 0,8640 & 57,21 \\
\hline Bioplastik (BPS-10) & 10 & 2,5 & 0,3296 & 0,6619 & 50,20 \\
\hline
\end{tabular}

Gambar 1 memperlihatkan pengaruh penambahan kitosan terhadap daya serap air pada bioplastik, semakin besar penambahan variasi kitosan maka nilai persen swelling bioplastik semakin meningkat. Hal ini dikarenakan kitosan mengandung gugus hidroksil (gugus $\mathrm{OH}$ ) yang bersifat hidrofilik. Gugus inilah yang mendorong serapan air pada bioplastik menjadi lebih tinggi. Proses terdifusinya molekul pelarut kedalam polimer akan menghasilkan sampel bioplastik yang mengembung. Peristiwa yang serupa pernah dilaporkan oleh Ban et al., (2005) dimana dalam penelitiannya yang menggunakan pati untuk pembuatan biofilm, bahwa penambahan kitosan kedalam matrik bioplastik dapat meningkatkan daya serap air. 


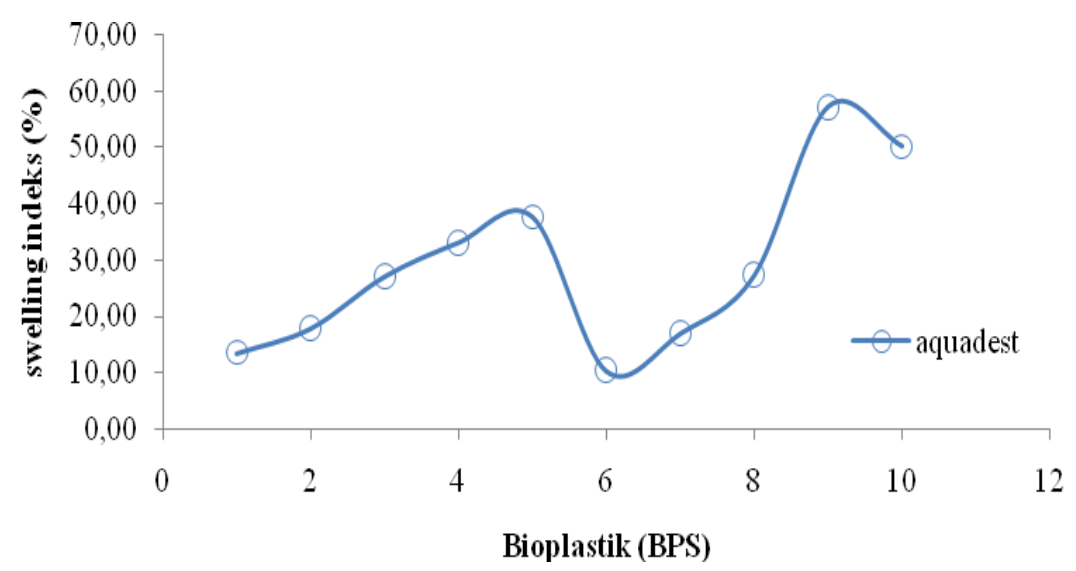

Gambar 1. Grafik hasil hubungan bioplastik terhadap swelling indeks.

Nilai uji swelling diperlihatkan pada Tabel 1 dimana nilai yang paling baik adalah diperoleh pada sampel BPS 6, dengan penambahan kitosan sebesar 0,5 $\mathrm{g}$ dan gliserol $10 \mathrm{ml}$ memiliki ketahanan terhadap air paling bagus dibandingkan dengan yang lainnya. Hal ini disebabkan karena gliserol yang terdapat pada sampel BPS-6 lebih banyak jumlahnya yaitu sebear $10 \mathrm{ml}$. pada sampel BPS-9 dan BPS-10 berbanding terbalik dari penelitian yang dilakukan Ban et al., (2005). Hal ini disebabkan karena tren penyerapan pada gliserol $10 \mathrm{ml}$ dipengaruhi oleh berat sampel karena ketebalan bioplastik yang berbeda-beda, hal itu dikarenakan saat casting pada pencetakan dilakukan secara manual sehingga mempengaruhi indeks swelling dan ketahanan airnya.

\subsection{Uji Kecepatan Daya Urai oleh Mikroorganisme di dalam Tanah (Biodegradable)}

Analisa degradasi bioplastik dilakukan melalui pengamatan secara visual 4 hari sekali dalam rentang waktu 16 hari. Bioplastik dapat dikatakan ramah lingkungan jika dapat terurai oleh mikroorganisme atau terdegradasi dengan baik. Pada penelitian ini untuk menganalisa kemampuan biodegradasi, setiap sampel bioplastik yang digunakan berjumlah sepuluh sampel dengan dimensi $2 \times 2 \mathrm{~cm}$.

Table 2. Hasil Uji Laju Biodegradabel

\begin{tabular}{|c|c|c|c|c|}
\hline \multirow{2}{*}{ Sampel } & \multicolumn{4}{|c|}{ KehilanganBerat (\%) } \\
\cline { 2 - 5 } & \multicolumn{4}{|c|}{ Hari ke- } \\
\cline { 2 - 5 } & $\mathbf{4}$ & $\mathbf{8}$ & $\mathbf{1 2}$ & $\mathbf{1 6}$ \\
\hline Bioplastik (BPS-1) & 43,13 & 93,64 & 100 & 100 \\
\hline Bioplastik (BPS-2) & 40,51 & 68,50 & 100 & 100 \\
\hline Bioplastik (BPS-3) & 34,22 & 47,70 & 85,80 & 100 \\
\hline Bioplastik (BPS-4) & 26,44 & 47,44 & 83,80 & 100 \\
\hline Bioplastik (BPS-5) & 23,45 & 40,38 & 79,15 & 100 \\
\hline Bioplastik (BPS-6) & 19,59 & 69,30 & 100 & 100 \\
\hline
\end{tabular}




\begin{tabular}{|c|c|c|c|c|}
\hline Bioplastik (BPS-7) & 21,90 & 48,05 & 85,38 & 100 \\
\hline Bioplastik (BPS-8) & 25,29 & 40,27 & 82,88 & 100 \\
\hline Bioplastik (BPS-9) & 33,71 & 48,86 & 75,43 & 100 \\
\hline Bioplastik (BPS-10) & 30,37 & 52,33 & 84,87 & 100 \\
\hline
\end{tabular}

Gambar 2 melukiskan peristiwa terdegradasinya bioplastik ramah lingkungan dari sampel BPS 1 hingga BPS 5. Pada penambahan kitosan sebesar 1,5 ; 2; dan 2,5 gr bioplastik terdegrasi lebih lama dibandingkan dengan penambahan kitosan sebesar 0,5 dan $1 \mathrm{gr}$, hal itu terjadi karena semakin banyak kandungan penguat alami didalam campuran BPS maka BPS termodifikasi akan lebih sulit untuk di degradasi.

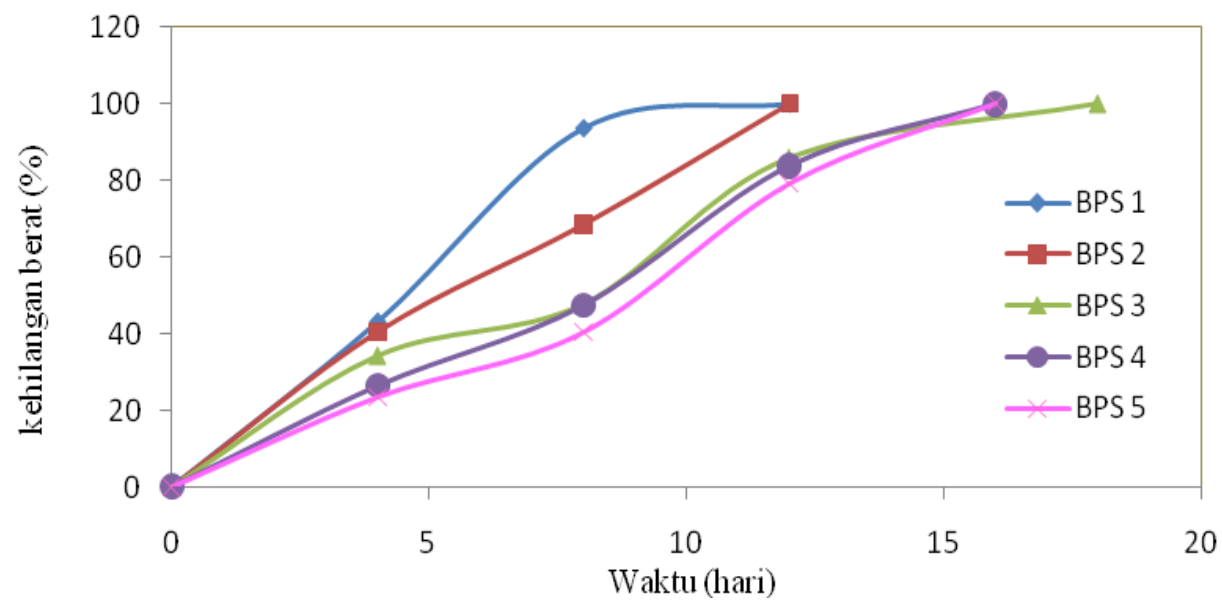

Gambar 2. Hubungan Kehilangan Berat (\%) Terhadap waktu daya urai pada Bioplastik (BPS)

Disamping itu, penyebab lainnya adalah karena kitosan juga memiliki sifat yang tahan terhadap serangan mikroorganisme pengurai yang terkandung di dalam tanah sehingga sampel bioplastik lama terurai, laporan yang senada juga pernah di sampaikan oleh Coniwati, (2014) dalam penelitian pembuatan film bioplastik dari pati jagung. Selain itu, dari Tabel 2 juga dapat diamati bahwa kehilangan berat $100 \%$ pada BPS-1 terjadi pada hari ke 12, pada BPS-2 terjadi pada harike 12 , pada BPS-3 terjadi pada harike 16, pada BPS-4 terjadi pada harike 16 , dan pada BPS-5 terjadike 16.

Dari Gambar 3 memperlihatkan tren grafik yang melukiskan laju kehilangan berat sampel BPS 6 sampai dengan BPS 10 dengan komposisi variasi gliserol sebanyak $10 \mathrm{ml}$. Perbedaan perbandingan penambahan gliserol sebesar 10 ml pada BPS-7 dengan kitosan $1 \mathrm{~g}$, bioplastik lebih lama terurai oleh mikroorganisme dibandingkan dengan BPS-2 yang mana penambahan gliserol sebesar $7 \mathrm{ml}$ dan kitosan $1 \mathrm{~g}$ hal ini dikarenakan berat gliserol lebih tinggi dibandingkan dengan BPS-2. Semakin banyak gliserol dan kitosan yang ditambahkan pada bioplastik, maka tingkat kerusakan bioplastik semakin rendah dan terdegradasi lebih lama. 


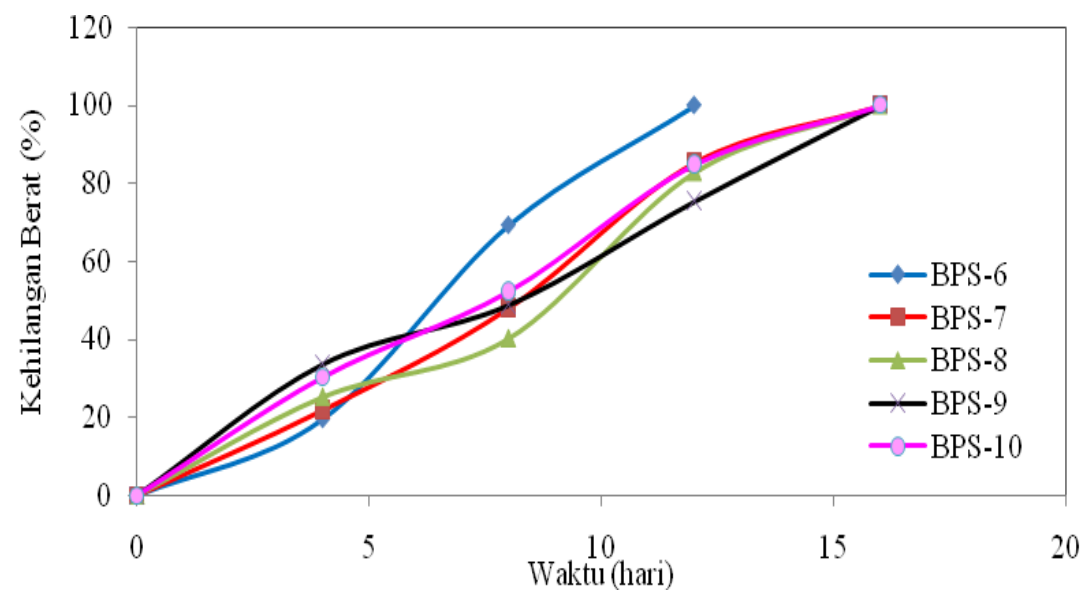

\section{Gambar 3. Hubungan Kehilangan Berat (\%) Terhadap waktu pada Bioplastik (BPS)}

Menurut Utami dkk., (2014) bioplastik mudah terdegradasi karena komponen penyusun didalamnya merupakan bahan alam. Bioplastik yang dihasilkan mengandung gugus hidroksil $(\mathrm{OH})$ dan gugus karbonil $(\mathrm{CO})$. gugus tersebutlah yang mengakibatkan bioplastik dapat terdegradasi dengan baik. Secara umum faktor-faktor yang mempercepat proses terjadinya biodegradasi adalah komponen larutan penyusun, struktur polimer, morfologi (Coniwatiet al., 2014). Hasil uji biodegradasi ini menunjukkan bioplastik berbahan pati biji alpukatkitosan dapat dikatakan sebagai plastik yang dapat terurai secara alami (biodegradable). Penambahan gliserol menghasilkan tingkat degradasi yang berbeda-beda dari bioplastik. Tingkat degradasi bioplastik tersebut dapat dilihat dari besarnya nilai persen degradasi.

\subsection{Uji Mekanis}

Dari hasil uji kuat tarik masing-masing memiliki nilai sifat mekanik yang berbeda beda walaupun dengan perlakuan yang sama. Hal ini disebabkan homogenitas dari campuran bahan plastik yang dihasilkan berbeda-beda. Suhu pada saat pengeringan sampel bioplastik juga mempengaruhi nilai kuat tarik bioplastik karena panas yang berlebih dapat membuat sampel memiliki rongaarongga sehingga dapat mempercepat terputusnya bioplastik.

\section{Kuat Tarik (Tensile Strength)}

Hasil uji kuat tarik dari bioplastik yang dihasilkan ditabulasikan dalam Tabel 3, dari hasil uji tersebut memperlihatkan bahwa hasil yang paling baik adalah diperoleh pada sampel BPS-10 dengan penambahan kitosan seberat 2,5 g dan memiliki nilai uji tarik sebesar $4 \mathrm{Mpa}$. Peristiwa ini menunjukkan bahwa semakin besar konsentrasi kitosan maka akan semakin banyak ikatan hydrogen yang terdapat di dalam bioplastik sehingga ikatan kimia dari bioplastik akan 
semakin kuat dan sulit untuk diputus. Peristiwa yang sama juga pernah di laporkan oleh Ani (2010) dimana plastik biodegradable dengan bahan pengisinya adalah kitosan memenuhi golongan Moderate Properties untuk kuat tariknya, yaitu 1-10 Mpa.

Tabel 3. Hasil Uji Kuat Tarik (Tensile Strenght)

\begin{tabular}{|c|c|c|c|c|c|}
\hline \multicolumn{3}{|c|}{ Gliserol 7 (ml) } & \multicolumn{3}{c|}{ Gliserol 10 (ml) } \\
\hline Sampel & Kitosan $(\mathbf{g})$ & Kuattarik & Sampel & Kitosan (g) & Kuattarik \\
\hline BPS-1 & 0,5 & 1,00 & BPS-6 & 0,5 & 1,00 \\
\hline BPS-2 & 1 & 2,00 & BPS-7 & 1 & 2,00 \\
\hline BPS-3 & 1,5 & 3,00 & BPS-8 & 1,5 & 2,00 \\
\hline BPS-4 & 2 & 3,00 & BPS-9 & 2 & 2,00 \\
\hline BPS-5 & 2,5 & 3,00 & BPS-10 & 2,5 & 4,00 \\
\hline
\end{tabular}

Gambar 4 memperlihatkan nilai kuat tarik dari bioplastik yang terbuat dari pati biji alpukat yang telah memenuhi syarat golongan Moderate Properties. Semakin banyaknya kitosan yang diimbangi oleh penambahan gliserol menyebabkan tidak semua kitosan dapat bercampur sempurna (distribusi kitosan yang kurang homogen) sehingga nilai kuat tarik setelah meningkat kemudian agak sedikit menurun.

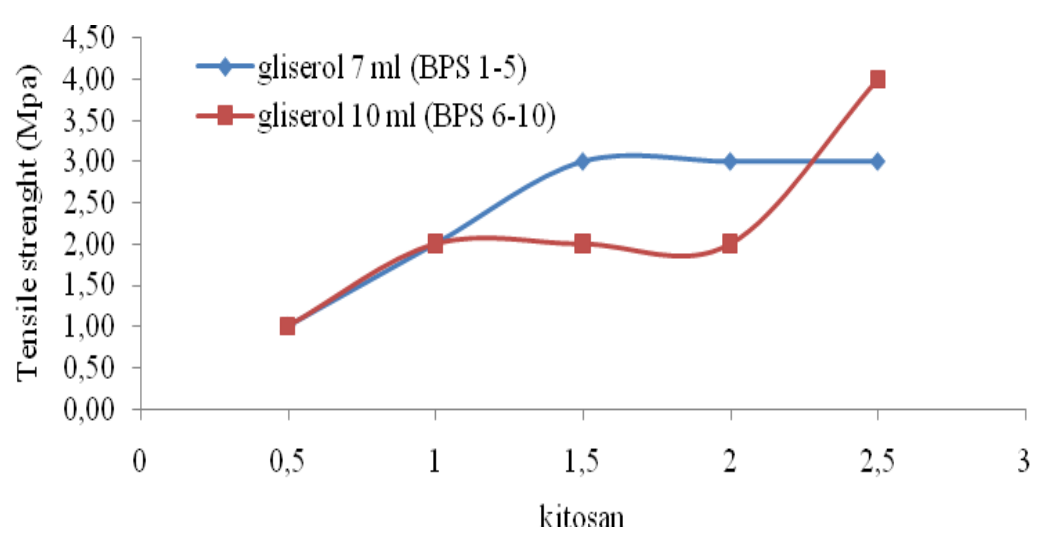

Gambar 4. Hubungan kuat tarik dengan komposisi kitosan dan gliserol

\section{Persen Pemanjangan (Elongasi)}

Persen pemanjangan mempresentasikan kemampuan bioplastik untuk merenggang secara maksimum. Tabel 4 memaparkan hasil uji elongasi bioplastik, dimana persen pemanjangan dengan penambahan gliserol $10 \mathrm{ml}$ memiliki nilai elongasi tertinggi pada sampel BPS_1 dengan penambahan kitosan sebesar 0,5 g menghasilkan nilai elongasi sebesar $54,50 \%$. Persen pemanjangan pada 
penambahan gliserol akan menaikkan nilai elongasi dari bioplastik. Elongasi berbanding terbalik dengan kuat tarik. Penambahan kitosan bias mereduksikan besarnya nilai dari elongasi bioplastik, hal ini mengindikasikan bahwa jumlah kitosan yang ditambahkan dapat menyebabkan penurunan jarak ikatan antar molekul. Penurunan jarak ini disebabkan oleh meningkatnya jumlah ikatan hydrogen yang terbentuk antara molekul kitosan-amilosa-amilopektin, hal serupa pernah dilaporkan oleh Ginting dkk., (2016).

Tabel 4. Hasil uji persen pemanjangan (Elongasi)

\begin{tabular}{|c|c|c|c|c|c|}
\hline \multicolumn{3}{|c|}{ Gliserol 7 (ml) } & \multicolumn{3}{c|}{ Gliserol 10 (ml) } \\
\hline Sampel & Kitosan (g) & Elongasi (\%) & Sampel & Kitosan (g) & Elongasi (\%) \\
\hline BPS-1 & 0,5 & 45,70 & BPS-6 & 0,5 & 54,50 \\
\hline BPS-2 & 1 & 44,50 & BPS-7 & 1 & 53,40 \\
\hline BPS-3 & 1,5 & 43,40 & BPS-8 & 1,5 & 52,30 \\
\hline BPS-4 & 2 & 42,40 & BPS-9 & 2 & 51,20 \\
\hline BPS-5 & 2,5 & 41,40 & BPS-10 & 2,5 & 50,20 \\
\hline
\end{tabular}

Meningkatnya jumlah ikatan hydrogen yang terbentuk membuat nilai persen elongasi semakin kecil dan bioplastik yang dihasilkan semakin kaku dan kurang elastis. Penelitian yang dilakukan oleh Hidayati, $d k k$., (2015) melaporkan bahwa penambahan gliserol mampu mengurangi kerapuhan dan meningkatkan fleksibilitas bioplastik, sehingga dapat disimpulkan bahwa penambahan gliserol inilah yang sangat berpengaruh terhadap nilai elongasi suatu bioplastik.

Elongasi cenderung mengalami peningkatan seiiring dengan bertambahnya volume gliserol dalam bioplastik. Peningkatan nilai elongasi terjadi karena gliserol mengganggu ikatan hydrogen antara molekul polimer yang berdekatan sehingga mampu mengurangi kerapuhan dan meningkatkan fleksibilitas polimer. Gliserol merupakan senyawa yang bersifat hidrofilik sehingga dapat melunakkan bahan dan mengakibatkan peningkatan nilai elongasi. Peningkatan nilai elongasi menyebabkan bioplastik tidak mudah putus/lebih elastic apabila terkena gaya (Mali $d k k .$, 2004).

Menurut Widyaningsih $d k k$., (2012) penambahan gliserol berbanding lurus dengan persen elongasi, artinya semakin besar penambahan gliserol maka nilai persen elongasi cenderung semakin besar.

\section{Simpulan}

Hasil analisis dari bioplastik didapatkan bahwa uji kuat tarik terbaik adalah pada sampel BPS-10, dengan jumlah kitosan 2,5 g dan gliserol $10 \mathrm{ml}$, dengan nilai kuat tarik sebesar $4 \mathrm{Mpa}$. Untuk nilai persen pemanjangan terbaik didapat pada sampel BPS-6 yaitu sebesar 54,50\% dengan komposisi kitosan 0,5 g dan gliserol $10 \mathrm{ml}$. Hasil daya serap air (swelling) yang terbaik didapat dari sampel BPS-6 sebesar $10,32 \%$ dengan suhu $30^{\circ} \mathrm{C}$, karena semakin kecil persen swelling pada bioplastik maka akan meningkatnya persen ketahanan terhadap plastik 
tersebut serta degradasi bioplastik terbaik terurai secara alami $100 \%$ di alam dalam kurun waktu 16 hari.

\section{Daftar Pustaka}

1. Ban, W. (2006), Influence of Natural Biomaterials on the Elastic Properties of Starch Derived Films: An Optimization Study. Journal of Applied Polymer Science, 15(3): 30-38.

2. Coniwanti, P. (2014) Pembuatan Film Plastik Biodegradable dari Pati Jagung dengan Penambahan Kitosan dan Pemlastis Gliserol. Jurnal Teknik Kimia Fakultas Teknik Universitas Sriwijaya: Palembang.

3. Dallan, P.R.M., P. Moreira., D. luz, L. Petinari. S.M. Malmonge., M.M. Beppu., S.C. Genari, \& A.M, Monares. (2006) Effects of Chitosan Solution Concentration and Incorporation of Chitin and Glycerol on Dense Chitosan Membrane Properties. Journal of Biomedical Materials Research Part B: Applied Biomaterials, 3(3): 394-405.

4. Darni, Y. (2010), Studi Pembuatan dan Karakterisasi Sifat Mekanik dan Hidrofibitas Bioplastik dari Pati Sorgum. Jurnal Rekayasa Kimia dan Lingkungan, Vol. 7, No. 4: 88 - 93.

5. Ginting, M.H.s., M. Kristiani., Y. Amelia, \& R. Hasibuan. (2016), The Effect of Chitosan, Sorbitol, and Heating Temparature Bioplastic Solution on Mechanical Properties of Bioplastic from Durian Seed Strach (DurioZibehinus). Int, Journal of Engineering Research and Applications, 6(1): 33-38.

6. Hidayati, S., A.S. Zuidar, \& A. Ardiani. (2015), Aplikasi Sorbitol pada produksiFilm dari Nata De Cassava. J Reaktor, Biodegradabel 15(3): 196-204.

7. Khantayanuwong, Somwang, Chutatip Khemarom dan Sumaida Salaemae. (2016), Effects os Shrimp Chitosan on The Physical Properties of Handsheets. Pulp and Paper Technology Program, Department of Forest Products, Faculty of Forestry, Kasetsart University.

8. Krochta, J.M. (2002), Properties as Raw Materials for Film and Coatings: Definitions, Current Status, and Opportunities. Boca Raton, FL: CRC Press.

9. Mackay, Richard G., Tait J.M. (2011), Handbook of Chitosan Research and

Applications. New York: Nova Science Publisher, Inc.

10. Mali, S., M.V.E. Grossmann., M.A Garcia., M.N Martino, \& N.E. Zaritzky. (2004), Barrier, Mechanical and Optical Properties of Plasticized Yam Starch Films. Carbohydrate Polymers, 56(1): 129-135. 
11. Purwanti, A. (2010), Analisis Kuat Tarik dan Elongasi Plastik Kitosan. Jurnal Teknologi, 3(2):99-106.

12. Shirai, M.A., Grossmann, M.V.E., Mali, S., Yamashita, F., Garcia, P.S., Müller, C.M.O. (2013), Development of biodegradable flexible films of starch and poly (lactic acid) plasticized with adipate or citrate esters, Carbohydr. Polym. 92: 19-22.

13. Utami, M.R, Latifah, \& N. Widiarti. (2014), Sintesis plastik Biodegadabel dari Kulit Pisang dengan Penambahan Kitosan dan Plasticizer gliserol. Indonesian Journal of Chemical Science 3(2):163-167.

14. Widyaningsih, S.,D Kartika, \& Y.T. (2012), Pengaruh Penambahan Plasticizerdan Kalsium Karbonat terhadap Karakteristik dan Sifat Biodegradasi Film dari pati Kulit Pisang. Molekul, 7(1):69-81.

15. Winarti, S dan purnomo Y. (2006), Olahan Biji Buah Trubus Agrisarana. Surabaya.

16. Yadaf, G. D dan D. V. Satoskar. (1997), Kinetics of epoxidation of Alkyl Esters of Undecyclenic Acid Comparison of Traditional Rout vs IshiiVenturello Chemistry. JAOCS. Vol 74(4). 397-407. 